\title{
Ivo Andrić: Against National Mythopoesis
}

\author{
Marina Antić
}

Ivo Andrić (1892-1975), the most well-known and celebrated South Slavic author of the $20^{\text {th }}$ century, makes a most memorable fictional appearance in Saša Stanišić's 2006 novel, How the Soldier Repairs the Gramophone. In a fever-induced hallucination, the young narrator sees Ivo Andrić attempting to jump the river Drina on a horse:

On our way to the hospital we stop at the bridge, because Ivo Andrić is trying to jump the river Drina on a horse. All of Višegrad is there dancing. Auntie Typhoon and Carl Lewis run a race across the bridge to open the program. Andrić, the Nobel Prize winner gives the horse some wine as they come running up.... There are hoof beats on the asphalt, and Ivo Andrić takes off. Do you think he'll make it? Grandpa asks. . . . Hard to say. ${ }^{1}$

The intertextual reference, of course, is to one of the mythical tales from The Bridge on the Drina, Andrićs most well-known novel, a chronicle of the famous Višegrad bridge in Bosnia and Herzegovina, from its moment of origin in the sixteenth century to the moment of its destruction in World War I. The majority of the novel's plot is set in the nineteenth and early twentieth centuries, and as Zoran Milutinović has persuasively argued, the novel is truly a story of Bosnia's modernization under Austro-Hungarian occupation, rather than a sweeping history of the bridge or the town on the Drina. ${ }^{2}$

The early chapters that recount the origins of the bridge in the mists of history, as it were, contain the mythical tale referenced in Stanišić: the story of the great epic hero, whose steed left tell-tale indentations in the stone on the banks of the river when he, once upon a time, before the bridge was built, bore the great hero across the river to the other side:

Great heroes lived on earth in those days, when the stone had not yet hardened and was soft as the earth and the horses, like the warriors, were of colossal stature. Only for the Serbian children these were the prints of the hooves of Šarac, which had remained there from the time when Kraljević Marko himself was in prison up there in the Old Town and escaped, flying down the slope and leaping the Drina, for at that time there was no bridge. But the Turkish children knew that it had not been Kraljević Marko (for whence could a Vlach and a bastard have had such strength or such a horse!) nor could it have been any but Đerzelez Alija on his winged charger which, as everyone knew, despised ferries and ferrymen and leapt over rivers as if they were watercourses. They did not even squabble about this, so convinced were both sides in their own belief. And there was never an instance of any one of them being able to convince another, or that anyone had changed his belief. ${ }^{3}$

1. Saša Stanišić, How the Soldier Repairs the Gramophone, trans. Anthea Bell (New York, 2008), 205-6.

2. Zoran Milutinović, Getting over Europe: The Construction of Europe in Serbian Culture (Amsterdam, 2011), 205-24.

3. Ivo Andrić, The Bridge on the Drina, trans. Lovett F. Edwards (Chicago, 1977), 17. I will follow Edwards' translation with minor modifications. 
Here, with Marko Kraljević and Alija Đerzelez, Serbian and Bosniak heroes of epic poetry, Andrić invokes the indigenous oral epic tradition in former Yugoslavia. ${ }^{4}$ This invocation carries with it the heavy baggage of nationalist conceptions of literature because national narratives originating in the nineteenth century were built around the supposed manifestation of the Volk spirit in this poetry. ${ }^{5}$ That the children's stories diverge only in the name of the epic hero riding the steed also succinctly captures the idea that national narratives in Bosnia, intimately connected to these epic tales, are merely mirror images of each other.

Ivo Andrić taking the place of Đerzelez or Kraljević in Stanišić’s version is, alas, no mere feverish hallucination: in the times since the Bosnian war of the 1990s, Andric has been elevated to a national hero (or a villain, as the case may be) of epic proportions on more than one occasion. Hero because he had received the international recognition of the Nobel prize in literature in 1961, and national because his oeuvre has been read, at least in the last three decades, as having established and recounted the essence of Serbian nationhood, much like the epic poems featuring Marko Kraljević did for the previous generation. Stanišićs inversion of Andrić and Marko Kraljević is thus not merely an irreverent playfulness with the most respected Yugoslav author, but a deeply sardonic comment on the national(ist) use and misuse of Andrić's literature in former Yugoslavia.

In what follows, I will aid Stanišić's effort to dislodge such nationalistic readings with a turn to Andrićs text, showing the ways in which the famous novel and the passages within it most often associated with nationalist appropriation speak against rather than for national mythopoesis. I will do so by re-focusing on the literary rather than what Enver Kazaz has aptly called historiographic readings of the novel, which is to say, by analyzing narrative strategies that illuminate Andrić's resistance to (romantic) nationalism of the

4. Oral epic poetry referenced here is the indigenous oral literary genre in former Yugoslavia. It is written in a recognizable decasyllabic verse; features well-known heroes like the two named here, often in battle with equally recognizable villains; and a number of set, recognizable stylistic devices, including the so-called Slavic antithesis. Traditionally performed accompanied by the one-string gusle instrument, the genre slowly died out in its oral form in the late nineteenth and early twentieth century. Oral epic poetry has played a crucial rule in the construction of national narratives in former Yugoslavia in the nineteenth century, most notably following Vuk Karadžić's collection and publication of these poems. In a Herderian Volk spirit, the national movements that would develop over the course of the century understood the epic poetry as an instantiation of the (South) Slavic spirit and thus, the basis for a national "reawakening." For an excellent analysis of how oral epic poetry came to play such a prominent role in national narratives in and around Bosnia, see Edin Hajdarpašić, Whose Bosnia: Nationalism and Political Imagination in the Balkans, 1840-1914 (Ithaca, 2015).

5. Nationalist conceptions of literature, per Enver Kazaz's succinct formulation, "take the nation and its identity as the main character of literary-historical narration." Literature, in turn, becomes a "national spiritual discipline," unimaginable without a nation and its very own, distinct language. The language-literature-nation triad is as unbreakable as it is circular. See Enver Kazaz, "Terminološka zbrka (Bosanskohercegovačka književna historija i studij književnosti u raljama političkih ideologija)" Razlika/Diff èrance: Časopis za kritiku i umjetnost teorije, no. 2 (2001), at https://www.scribd.com/document/123471274/ Kazaz-Terminoloska-zbrka (last accessed June 11, 2018). 
nineteenth century. The key to national mythopoetic (mis)understandings of his oeuvre lies precisely in the resonances of epic literature in this novel, and in particular, Andrićs seeming reproduction of the epic narrative mode. In conclusion, I argue instead that Andrićs particular narrative style captured in the analyzed passages represents what Franco Moretti has called a modern epic-a world-text that desires the epic encyclopedic vision, but that also recognizes it cannot believe in it. ${ }^{6}$ This, rather than national mythopoesis, I propose, is the value and relevance of Andrićs contribution to world literature.

\section{Andrić as National Hero/Villain}

The national narrative spun around Andrić has held firm in both academic circles and popular imagination, despite several comprehensive attempts at correcting such appropriations of Andrić's oeuvre for national canons. ${ }^{7}$ The nationalist misreading of the novel mostly concerns its first half, set in Ottoman times, and most often, with just the first three chapters that recount children's stories and myths about the bridge: the departure of young Mehmed Paša Sokolović for Istanbul as one of the children taken in devşirme, the building of the bridge itself, and the infamous scene of impalement, respectively. ${ }^{8}$ On the basis of these texts, but especially the devşirme and impalement scenes, a nationalist interpretation of the novel has presented Andrić as the bard of Serbian historical suffering in the Balkans.

Examples of such reductive readings have been presented on numerous occasions, so I will only point to two, both occurring at the height of this nationalist pitch: a 1996 article by Radovan Vučković, "Andrićs Tale of a Victimized Nation," and the posthumous publication of Muhsin Rizvićs's Bosnian Muslims in Andrić's World in 1995. ${ }^{9}$ Vučković argues that the subject of Andrićs "epic" tale is the suffering of the Serbian people, with a straight line leading from Ottoman times to the war of the 1990s:

Even though Andrić is by nature a subtle poet and produces something we could call metaphysical poetry in narrative form, his merit lies precisely in having felt the magnificent epic drama and victimhood of Serbs in Bosnia in the long historical gloom officiated by two occupiers: Turkey and Austria-Hungary. ... Today, when much is said about borders and bridges on the Drina, we ought to read The Bridge on the Drina again.... Because,

6. Franco Moretti, Modern Epic: The World-System from Goethe to García Márquez trans. Quintin Hoare (London, 1996).

7. See for example, Ivo Žanić "Pisac na osami: Upotreba Andrićeve književnosti u ratu u Bosni i Hercegovini," Erasmus: Časopis za kulturu demokracije, no. 18 (November 1996): 48-57; Enver Kazaz, "Egzistencijalnost/povijesnost Bosne-Interpretacija u zamci ideologije” Novi izraz: Časopis za književnu i umjetničku kritiku, no. 10-11 (2001): 120-36; Celia Hawkesworth, "Ivo Andrić as Red Rag and Political Football," The Slavonic and East European Review 80, no. 2 (April 2002): 201-16.

8. Mehmed Pasha Sokollu (1506-1579), the inspiration for Andrić's character, was a well-known Ottoman vizier hailing from Bosnia, who, having risen through the ranks, ruled with the title of Grand Vizier from 1565 until his death.

9. Radovan Vučković, "Andrićeva priča o stradalničkom narodu.” reprinted in Andrić: Paralele i recepcija (Belgrade, 2006), 83-98; Muhsin Rizvić, Bosanski Muslimani u Andrićevu svijetu (Sarajevo, 1995). 
The Bridge on the Drina may indeed be a story of bridge building, but, it is apart from all else, a poema of Serbian suffering directly related to the bridge, and how such suffering is renewed from one generation to the next. ... In that novel, Andrić showed how the times of suffering and victimhood of Serbs in Bosnia are cyclically renewed. The first such victim by the bridge on the Drina, still in its construction, was the less than presentable peasant Radisav of Unište. ${ }^{10}$

Andrić's novel is read here as national mythopoesis because it supposedly captures the "magnificent epic drama" and the cyclical renewal of Serbian destiny. Vučković reads Andrić here in both an epic key (magnificent epic drama, poema) and a historiographic one (representing Serbian suffering throughout history).

Rizvić's volume, on the other hand, attempts to demonstrate that an imago of Ottoman Bosnia and Bosnian Muslims in Andrić's works reveals a level of hatred for all things Bosniak. Rizvić reads this in both the author's view of history and his literary output, with the two often inextricably intertwined. As Enver Kazaz summarizes, Andrić in this process become a "key argument of right wing ideologies in their mutual settling of accounts."11

Much like the children in Andrić's novel, who agree on everything except whose epic hero it was on that mythological steed, nationalistic readings agree on the basic myth, namely, that Ivo Andric portrays Bosnia as the site of unmitigated and unresolved ethnic violence, and that the author himself has "decidedly determined the current state of Serbian right wing ideology, grounding it in his own interpretation of history." 12 The only disagreement among them is, of course, the degree of Andrićs historical accuracy. Serbian nationalistic accounts claim the great author merely recorded the historical victimhood of the Serbian nation at the hands of the Ottomans (and thus, by extension, Bosniaks), while the Bosniak nationalistic accounts claim such accounts of victimhood are fueled by Islamophobia.

These ideological operations are grounded in a paradoxical reading of Andrić's text as historiography: Andrić merely "perceives" and captures something essential about Serbian history (and records it in epic form, as only befits South Slavic national tradition).$^{13}$ Because nationalism as an ideology is constructed on historiographic arguments (however flawed they may be), when Andrić's text is read as national mythopoesis, such readings cannot but evidence a conflation of fact and fiction. As Enver Kazaz says: Andrićs oeuvre has not in fact been read as a literary but rather a historiographic text, which is

10. Vučković, “Andrićeva priča,” 86-88, emphasis added.

11. Kazaz, "Egzistencijalnost," 121.

12. Ibid.

13. Compare such readings with, for example, the role two composed epic poems played in constructions of Herderian nationalist mythology: Ivan Mažuranić's The Death of Smail-Aga and Petar Petrović Njegošs The Mountain Wreath. The nationalist readings of Andrić take him as a continuation of this epic tradition, rather than its overcoming. For an analysis of how even Njegoš's poem is often misread as a political justification of nationalist expansion, see Srđa Pavlović "The Mountain Wreath: Poetry or a Blueprint for the Final Solution?” Space of Identity 1, no. 4 (December 2001) at www.soi.journals.yorku. ca/index.php/soi/article/view/8038/16949 (last accessed June 11, 2018). 
then in turn either taken for a type of unconditional truth/scientific accuracy or for a type of unconditional untruth/hatred for which no arguments can be found in history itself. ${ }^{14}$ Ivo Žanić likens the effect of such readings to Alice in Wonderland:

These are the readers who intentionally transformed Andrićs literary oeuvre into a magical mirror that any naive and confused Alice can use to enter the Wonderland and come out the other side (when she gets bored) self-confident and assured that she has finally understood all that had eluded her before. The ruins and the graveyards she saw on the other side were part of a quite convincing stage design, while inhabitants were merely characters in one charming novelistic plot.

The prop master is to be congratulated: the blood was like the real thing. ${ }^{15}$

And so we arrive at the point that had eluded our Alice, that she will finally now understand, having read Andrić: ethnic conflict in the Balkans is the one constant, defining feature of the region, nations are born in medieval times and move through history unchanged and unchangeable, and the war and destruction we witnessed in the 1990s is nothing but the logical end point of battles begun 500 years ago. This is precisely how Andrić, the most cited literary author in all political rhetoric about former Yugoslavia, has been understood: as a "key to understanding the history of Yugoslavia," as "evidence" of ancient hatreds in Bosnia and Herzegovina, or as an infallible guide through the confusing history of the Balkans as a whole. ${ }^{16}$

As already mentioned, others have argued against such readings of Andrić with alternative readings of his oeuvre. Celia Hawkesworth builds from Andrić's biography into his dissertation; moves into a close reading of the short story The Letter from 1920; and concludes on the broader features of Andrićs aesthetic, namely, the universal essentialist patterns of human experience captured in particular Bosnian realities. ${ }^{17}$ Enver Kazaz, however, indicts such attempts to balance out the carelessness of nationalist readings by "bypassing all layered complexity of the historical picture, finding only

14. Ibid., 122, emphasis in original. Treatment of Andrić's fictional output as history is also evident in a number of other cases, including the conflation of historical and fictional figures of 19th-century Sarajevo, as I've argued in "Historicizing Bosnia: Kosta Hörmann and Bosnia's Encounter with Modernity," in Clemens Ruthner, Diana Reynolds Cordileone,Ursula Reber and Raymond Detrez, eds., WechselWirkungen: Austria-Hungary, Bosnia-Herzegovina, and the Western Balkans, 1878-1918 (New York, 2015), 331-62.

15. Žanić, "Pisac na osami," 57.

16. For a sampling of relatively recent commentary in this vein, see, for example, among others, Charles Crawford on the short story "A Letter from 1920" in "Bosnia's Irreconcilable Principles," TransConflict, July 24, 2012 at www.transconflict.com/2012/07/ bosnias-irreconcilable-principles-247/ (last accessed June 11, 2018), or Benjamin S. Lambeth on The Bridge on the Drina in NATO's Air War Kosovo: A Strategic and Operational Assessment (Santa Monica, 2001), 5; or Milorad Dodik on reading Andrić to understand life in Bosnia in "Dodik: Kad imam vremena čitam Andrića da lakše shvatim život u BiH" in Poskok International Edition, June 28, 2012 at www.poskok.info/dodik-kad-imamvremena-citam-andrica-da-lakse-shvatim-zivot-u-bih/ (last accessed June 11, 2018); and many more. Even a cursory search of Ivo Andrić will turn up a plethora of articles in the popular press that reference Andrić in relation to the 1990s Yugoslav wars.

17. Hawkesworth, "Ivo Andrić as Red Rag," 205. 
universal essences, metaphors of one, single, supratemporal reality." ${ }^{18} \mathrm{He}$, on the other hand, argues that Andrić's oeuvre is "based in the polyphonic and dramatically postulated contrapuntal structure," whose individual elements are (mis)read as independently mimetic. ${ }^{19}$ Andrew Wachtel, like Kazaz, relies on Andrić's essay Conversations with Goya in foregrounding the archeological metaphors outlined there. He reads Andrićs historical novels "in dialogic iteration" of the diachronic and synchronic "archeological cuts." 20 This allows Wachtel to offer a different "national" reading of Andrić, namely, as a Yugoslav "national imaginer," whose first person plural narration establishes a particular dialectic between the "radical discontinuity" and "remarkable continuity" in the historical experience of Yugoslavs. ${ }^{21}$

Like Kazaz and Wachtel, I will attempt to answer the politically-careless readings with references to narrative contrapuntal structures in Andrić, respecting Kazaz's injunction against a reading of Bosnian history subsumed into essentialist universalisms. My contribution in this sense is a new reading of the structural integration of epic features into this modernist novel, constituting, as I will argue, a form of a specifically Bosnian modern epic. At the same time, I also follow up on Hawkesworth's strategy of "careful reading" by close reading not The Letter from 1920 like she has already done, but the scenes that are at the forefront of all national (mis)readings that to my knowledge have not yet been close read. Close reading may certainly not give us the broader political context or reception of the work, but as Kazaz has suggested, in the reception of Andrićs oeuvre, it is precisely the (modernist) literary text itself that gets overlooked. It seems to me that there is no better strategy for bringing it forth than close reading-the modernist reading practice par excellence. ${ }^{22}$

Ivo Žanić admits that Andrić is particularly susceptible to imagological readings and specifically signals the scene of impalement in chapter three as one of the key moments in The Bridge on the Drina, which because of its staggering brutality has been the lightning rod for "misunderstandings and manipulations of the author's oeuvre."23 Oft-mentioned, including in Vučković and Rizvić above, but rarely closely read or extensively cited, undoubtedly because of its gruesome nature, the scene in question occurs early in the novel, when the Ottoman authorities publicly execute a rebellion leader by impaling him at the site of the future bridge.

Žanić cites at least one direct invocation of the impalement scene as a "pensée imagée, the point of origin for the irreversible development of the mechanism of collective hallucination" in relation to a real life case, about which Branko Krkeljić said that the perpetrators "impaled [the victim] on a bottle and a stake, as once upon a time the Janissaries did to the Serbian

18. Kazaz, “Egzistencijalnost,” 136.

19. Ibid.

20. Andrew Wachtel, "Imagining Yugoslavia: The Historical Archeology of Ivo Andrić," in Wayne S. Vucinich, ed., Ivo Andrić Revisited: The Bridge Still Stands (Berkeley, 1995), 85.

21. Ibid., 94.

22. For more on close reading as a modernist reading practice see Fredric Jameson's $A$ Singular Modernity: Essay on the Ontology of the Present (London, 2013).

23. Žanić, "Pisac an osami," 53. 
peasant Radisav in Andrićs novel." 24 This reference in fact conflates two images from the novel that have been at the heart of reading Andrić in the epic key: the scene of the Janissaries taking away young Mehmed paša Sokolović on the one hand, and the scene of Radisav's impalement, on the other. In what follows, I will turn to both scenes in some detail in order to unravel their many misinterpretations, from those that see in them the portrayal of Serbian national victimization to the ones that stay within the fictional text, but still overlook ways in which Andrić qualifies the epic features of these scenes. ${ }^{25} \mathrm{I}$ show instead that Andrić uses them, among others in this novel, in order to disrupt epic narrative models that underwrite much of South Slavic national invention of tradition, and thus challenge rather than affirm national(istic) models of Bosnian history.

\section{The Black Line (Crna pruga)}

The scene involving the Janissaries, when the young boy Sokolović is taken away to Istanbul to join the elite corps of slave soldiers, is a depiction of the practice of devşirme, or blood tribute. Most positivistic interpretations focus on the moment the young Sokolović is taken by the Janissaries as the moment of origin for Serbian suffering in the so-called dark-vilayet Bosnia. ${ }^{26} \mathrm{~A}$ closer look at Andrićs narrative structure and the narrative "close-ups"-Zdenko Lešić introduces this cinematic term to describe the particularly frequent changes in perspective and character zones typical of most of Andric's fiction-will show how the tragedy of this scene is qualified by a more existential moment of (artistic) inspiration. ${ }^{27}$

24. As quoted in Žanić, "Pisac na osami," 55. The reference is to the so-called Martinović case-a Kosovar Serb found sodomized by a glass bottle near Gnjilane, and, in particular, Brana Crnčević's reformulation of the injuries sustained by Martinović from sodomization by bottle to "impalement by a stake packaged in a bottle." Others went even further in proposing psychological explanations for the prevalence of this image in nationalist propaganda, but I find even Žanićs argument to be stretching the effects. See, in particular, Lynda E. Boose "Crossing the River Drina: Bosnian Rape Camps, Turkish Impalement, and Serb Cultural Memory," Signs: Journal of Women in Culture and Society 28, no. 1 (Fall 2002): 71-96, as one of the only publications that cites almost the entire scene from the novel.

25. I am using epic here to denote two key features as will become clear shortly: Radisav's supposed epic martyrdom on the one hand, and formal epic narrative features on the other, including a "distant" third person narrative, interrupted or constructed through narrative digressions that connect, in the end, into a grand, sweeping view of history perceptible only from some imaginary Andrićesque "Olympus." For more on the epic mode in Andrić, see especially Zdenko Lešić, Pripovjedači: Ćorović, Kočić, Andrić, Samokovlija, Humo (Sarajevo, 1988).

26. Dark-vilayet (tamnovilajetski) is an adjective naming the typical Orientalist reading of Bosnia during the Ottomans as the barbaric heart of darkness of the Balkan Peninsula. Zdenko Lešić traces this type of reading to Isidora Sekulić's influential article "Istok u pripovetkama Iva Andrića” in Pripovjedači, 174. On Sekulić's reading of Andrić see also Tomislav Longinović, "East within the West: Bosnian Cultural Identity in the Works of Ivo Andrić” in Wayne S. Vucinich, ed., Ivo Andrić Revisited: The Bridge Still Stands (Berkeley, 1995), 123-38.

27. Lešić, Pripovjedači, 141. 
The narrator first describes this particular scene from afar:

The chosen children were laden onto little Bosnian horses in a long convoy. On each horse were in tow plaited panniers, like those for fruit, one on each side, and in every pannier was put a child, each taken from their parents' homes. ${ }^{28}$

Then he moves very closely to the perspective of the children's mothers:

A little behind the last horses in that strange convoy straggled, disheveled and exhausted many parents and relatives.... the mothers were especially persistent and hard to restrain. Some would rush forward not looking where they were going, with bare breasts, and disheveled hair, forgetting everything about them, wailing and lamenting as at a burial, while others almost out of their minds moaned as if their wombs were being torn by birth pangs, and blinded with tears ran right onto the horsemen's whips. ${ }^{29}$

Here the national(istic) reading stops. The brutality of the Janissary system, the "stealing” of children, ripped from the mother's (nation's) womb as described here are inevitable points of focus in such readings. Rizvić claims that the "emotional charge of this scene is designed as a romantic appeal to the readers' emotions," while Andrić's "development of this first scene of violence and conversion" completely "determines the archetypal antagonism and the hatred's origin as the ideological features of this novel." 30 We can agree with Rizvić about the emotional charge of the scene, even if do not follow him into the "archetypal antagonism" he then reads into Andrić.

Importantly, however, the narrative continues, changing perspective yet again to that of the young boy who is to become one of the most important and influential Grand Viziers in the Ottoman Empire: "On that November day in one of those countless panniers a dark-skinned boy of about ten years old from the mountain village of Sokolovići sat silent and looked about him with dry eyes. In a chilled and reddened hand he held a small curved knife with which he absent-mindedly whittled at the edges of his pannier, but at the same time looked about him." ${ }^{31}$ Here the young Sokolović is separated from other children who are crying, visibly upset, or those who "gazed calmly ... looking as long as they could at their native land,"32 or those who simply slept. He is, like some of them, looking about, but importantly, it is not simply "native land" that he remembers, but something far more specific:

He was to remember that stony bank overgrown with sparse, bare and dull gray willows, the surly ferryman ... As a physical discomfort somewhere inside himself-a black line that would from time to time, for a second or two, cut his chest in two and hurt terribly-he carried within himself the memory of that place where the road broke off, where desolation and despair were condensed and sedimented on the stony banks of the river, across which passage was so difficult, so expensive and so unsafe. This was a particularly hurtful and painful spot in that hilly and poverty-stricken district, where

28. Andrić, The Bridge, 24.

29. Ibid.

30. Rizvić, Bosanski Muslimani, 172.

31. Andrić, The Bridge, 25.

32. Ibid. 
misfortune was open and evident, where man would be halted by an overpowering elemental force and, ashamed of his powerlessness, would be forced to recognize more clearly his own misery and that of others, his own backwardness and that of others. ${ }^{33}$

That pain described here is very specifically tied neither to a general regret at having left the land of his origin, nor to the separation from his family, but rather the impression of the poverty-stricken district, human powerlessness against the brute forces of nature, and the misery and backwardness of his home, all of which become the inspiration to build the bridge:

In one of those moments he felt that he might be able to free himself from this discomfort if he could do away with that ferry on the distant Drina, around which so much misery and inconvenience gathered and sedimented incessantly, and bridge the steep banks and the evil water between them ... and thus link safely and forever Bosnia and the East, the place of his origin and the places of his life. ${ }^{34}$

In that moment, the Grand Vizier sees, in his mind's eye, the "firm graceful silhouette of the great stone bridge." 35 The bridge functions to relieve this painful "black line" that cut his chest in two ways: first as a demonstration of man's ability to tame and thus assert power over nature (bridging the steep banks and evil water between them) and second, as a way to link his two spatial coordinates, the peripheral province of his birth and the center of empire from whence he rules over it.

In the shifting of perspectives I've quoted here at length we can also see the way in which the initial, tragic scene is qualified by the boy's perspective-Sokolović is not despairing simply for being taken away from Bosnia or even for being forced to convert to Islam as the mothers are, but rather mourns the poverty, backwardness, and death itself personified in the ferryman and the crossing of the river. ${ }^{36}$ He focuses instead on the poverty and backwardness of the province, the most peripheral part of the empire (is he already thinking like a statesman at ten years of age?), and that the only way to solve that feeling of being cut in two is to join that periphery to the center, Bosnia and the East, as if that one bridge could at least be a beginning of the deperipheralization of his place of origin. His inspiration for the bridge is thus born out of this pain and offers itself as a resolution to his conflicted life in the imperial center far away from his provincial, desolate homeland. ${ }^{37}$

33. Ibid., 25-26. Emphasis added.

34. Ibid., 26.

35. Ibid.

36. There are numerous hints about death and crossing into the otherworld in the passages describing the ferryman. Andrić references several mythologies and their respective ferrymen controlling the afterworld: like Charon in Greek mythology, he is in a foul mood, gigantic and strong, unkempt, and cranky. Like Malik in Islamic mythology, Jamak never smiles; like Dea Tacita in Roman mythology, he is the personification of the terror of obscurity. Blackness alludes to Ancient Slavic Chernobog, while the name itself-Jamakrefers to a Persian mythological character, a God of death and hell in Hindu, Persian, and even Buddhist traditions.

37. The question of empire, and in particular, the legacy of the Ottoman Empire in constructions of Balkan identity, is a topic well beyond the scope of this paper. One of the 
Finally, in his imagination the bridge arises also as an art form, graceful and firm (as opposed to purely utilitarian) and hints at a frequent theme in Andrić's texts: art in confrontation with death, bridge rather than the ferryman, beauty rather than death. We will see this theme again in this novel in Corkan's transcendental crossing of the bridge parapet, dancing, much like Aska in front of the wolf in Andrić's short story. ${ }^{38}$

And yet, Sokolović seems to fail on both accounts: the bridge is built, but it fails to unify his two divided halves and it fares no better in confrontation with death. The same year the bridge is built, Sokolović is to feel that wellknown pain that split his chest in two, except this time it is delivered by a crazed dervish who stabs him to death. In death, Sokolović is transformed once again into the peasant he would have been had he never left Bosnia:
Soon after the bridge was finally finished, just as the karavan-saraj opened up, and the bridge earned its prestige around the world, Mehmed-paša felt once again that "black razor" pain in his chest. And this was the last time. ... Next to [his murderer] lay the great Vizier, his long shirt undone on his chest and his coat thrown aside. The last few years of his life he lost weight, rounded in his shoulders, and became somehow withered and coarser in his face. And now, just like that, undone and bareheaded, bent and sunken in, he resembled more an aged and beaten down peasant from Sokolovići than a slain dignitary who up until a minute ago ruled the Ottoman Empire. ${ }^{39}$

Even the most powerful of men, as Andrić would often show in his fiction, are cut down by history, by the great maelstrom that sweeps up the most powerful as swiftly and as surely as the least powerful. ${ }^{40}$ Sokolović's transformation also signals that the apparent splitting of his chest in two is no mere illusion-the peasant had continued to live within him, and with death, he comes back.

On the other hand, as Sokolovic is struck down by that same pain that the bridge was supposed to relieve, the artistic impulse does not deliver him from death, the way Scheherazade's storytelling or Aska's dancing does. The trace of this life and death struggle, however, marks the bridge forever. ${ }^{41}$ In the

most significant interventions is Maria Todorova's Imagining the Balkans (Oxford, 1997), which effectively inspired an entire scholarly subdiscipline. I engaged this subject (and the discipline's intellectual trajectory) in some detail in my dissertation, but the present work is attempting a shift in emphasis, away from imperialism and Balkanist discourse in reference to the Ottoman Empire, and towards a story of more structural features of Andrić's Bosnia in the modern period. As will be clear shortly, I am in agreement with Zoran Milutinović who reads Andrićs novel not as a long durée history of Višegrad, but as a story of the arrival of Austro-Hungarian empire into the region.

38. Ivo Andrić, “Aska i vuk” in Odabrane pripovetke knj. 2 (Belgrade, 1954), 532-42. This fable features a young female sheep confronting death in the guise of a hungry wolf by dancing in front of him and mesmerizing him with her dance.

39. Andrić, The Bridge, 72.

40. See Slavko Leovac, Pripovedač Ivo Andrić (Novi Sad, 1979), 186-89: "Everywhere and in the last instance all that remains is the suffering and humiliated man, but also time that unremittingly flows and flushes away the silt: both the terrifying and the laughable, the pathetic as well as the majestic, pain as well as joy."

41. See Dušan Pirjevec, "Andrićev Na Drini most," Slavistična revija: Časopis za jezikoslovje in literarne vede 26, no. 2 (April-June 1978): 115-46. 
rest of the novel, the bridge's immortality, its perceived permanence, not only punctuates the narrative, but also forms the unconscious philosophy of the town and its inhabitants. That art is the only human intervention in history, the only way humans can reach for the transcendental, is affirmed repeatedly in the novel.

Looking back to that original scene with the ten-year-old Sokolović, we may ascribe his unusual experience of the devşirme to his decidedly exceptional nature-he did after all rise to "heights of power and authority unknown to us, which few men reach and few men keep," but the narrator does not allow us to forget, by the second half of the novel, the scene with the mothers, and with them the "romantic appeal" of the national epos. ${ }^{42}$ The scene with the mothers running after their children who are being taken to serve an imperial army repeats itself in the second half of the novel:

A far greater commotion than that made by the recruits themselves was made by the women, mothers, sisters and other relatives of the young men who had come from distant villages to say farewell, to see them for the last time, to weep, to wail and to give them some last gift or final sign of love. . . . In vain it had been earlier explained to them in their villages that the young men were going neither to war nor to slavery, but that they would serve the Emperor in Vienna, and be well fed. ... All that passed over their heads like the wind, foreign and completely incomprehensible. They listened only to their instincts and would only be guided by them. These ancient and inherited instincts brought tears to their eyes and a wail to their throats, forced them persistently to follow as long as they could and try to get a last glance at him whom they loved more than life and whom an unknown Emperor was carrying off into the unknown. ${ }^{43}$

This "situational rhyme" in Lešić's terminology works two ways: first to suggest that as much as the mothers in the second scene were overreacting so were the ones in the first scene, and alternatively, to suggest that while the mothers were being reassured that their children now, in the early twentieth century, will come to no ill in being conscripted into the Austro-Hungarian army (and they initially do not), they do have much more in common with those Ottoman-era mothers in that their children are taken away to serve in a foreign, imperial military to be maimed or die.

At first, these mothers seem simply irrational, guided by "ancient instincts," and much as we were identifying with the tragedy of the mothers at the beginning, here we laugh at their unreasonable and overly dramatic send off. Soon enough, however, we will witness the mothers' "ancient instincts" confirmed by reality. Unlike the young Sokolović who not only comes to no ill, but rises to unimaginable power, these young recruits will all become cannon fodder in World War I. Naturally, we, as readers, already "know" this-and this is where Andrić's narrative takes on another level of ironic suggestion, a quality Slavko Leovac describes as "a position of a chronicler; the one who knows (and knows much more than is necessary for the story he tells)." ${ }^{44}$ As

42. Andrić, The Bridge, 26.

43. Andrić, The Bridge, 170.

44. Leovac, Pripovedač, 194. 
often happens in the novel, here too we can see how Andrić challenges the modernizing narrative that perceives Austria-Hungary as progress, civilization, and rational advancement to everyone's interest, and with it, the inverse perception of everything Ottoman as barbaric and backward.

Much of the novel, in fact, is devoted to comparing the two empiresOttoman and Austro-Hungarian-with a surprising focus on how the latter is only seemingly more "civilized" and less brutal than the former. In chapter fourteen, we learn how the Austro-Hungarian modern empire exerts even more control on the natives than the Ottoman, but does it in an only seemingly less brutal but in fact more insidious way: extracting even more ("it got as much or more, even more swiftly and surely"), while restricting even more the few pleasures of life ("vices were punished and enjoyments paid for even more heavily and dearly than before") all the while providing "its fata morgana of comfort, security, and happiness for all and everyone at reasonable prices and even on credit terms." ${ }^{45}$ As Zoran Milutinović has argued, The Bridge on the Drina is thus less about the history of the town of Višegrad and more about the modernization of Bosnia, the social transformation economic development engenders, the effects of the tireless "destructive creation" of capitalism, and the great bureaucratization of life itself. ${ }^{46}$

A key symbol of these processes, and the very thing that undermines the centrality of the bridge in the life of the town, is the train and the new railway line that bypasses and excludes the bridge from modern transportation networks. ${ }^{47}$ Whereas the bridge connected the Bosnian periphery to the pre-modern imperial Ottoman center, the railway connects this newly-minted Austro-Hungarian periphery to the broader network of extractive capitalism and its global center in Europe. The symbolic opposition of the bridge and the train, the pre-modern space-time and modern order, and, last but not least, feudalism and capitalism as key concerns of the novel, is also signaled in the unusual phrase crna pruga (black line) to designate Sokolović's physical discomfort as it parallels the pruga (railway line) that marks Bosnia's entry into global capitalism. I will return to these points in the conclusion.

\section{The Stake (Kolac)}

While Sokolović does not live to see the bridge materialized, the effects of its construction in that poverty-stricken district are initially merely more poverty and misery. The conflict that is to result in the young peasant's impalement is set up in the third chapter when we are introduced to both Abidaga-the corrupt, unhealthy, and mythically-evil Vizier's Trustee-and Radisav-his nemesis, a rebellious peasant who dared to stop the construction of the bridge, Abidaga's only task.

The medieval peasants as well as the townsfolk have little understanding of the bridge's construction, especially because of the immense need for labor and resources. The peasants are desperate to end the construction that has

45. Andrić, The Bridge, 173-75.

46. Milutinović Getting over Europe, 205-24.

47. Ibid., 217. 
already lasted three years but shown no sign of the bridge that is to span the river. Under Abidaga's tyranny, they have almost completely abandoned their fields and are starving. The Muslim townsfolk and landowners are actually in agreement with their peasants: while the promised bridge is a "great endowment" by the Grand Vizier who is originally from their town, the "chaos, turmoil, labor and expense" are turning them against the whole thing: "Their town turned into hell, a witches' Sabbath of incomprehensible activities, smoke, dust, screams, and commotion. Years have passed, the construction expands and grows, but one can't see their end or their purpose. This looks like all kinds of things, but a bridge? No." 48

This agreement of the natives against the building of the bridge, which is to be repeated at other times in the novel, begins to blur the lines between the evil Abidaga and the heroic Radisav and their respective communities. The Muslim townsfolk and landowners have much more in common with the Orthodox peasants than with the strange folks surrounding this alien construction. Important to note here is the tone of the narrator, "who knows more than is necessary to tell the story," a tone with which it is easy to identify (the narrator and the reader are "in the know," privy to a modern understanding of the history that is to follow) and therefore easy to follow into the symbolic minefield that is Radisav.

The oral epic form makes its first direct appearance here: a Montenegrin with the traditional gusle instrument communes around him a circle of poor and overworked peasants who are mesmerized with his songs of great Serbian victories and quests against the Ottomans:

The peasants are pressing closer and closer around the singer but without making the slightest noise; their very breathing can't be heard. They blink repeatedly, carried away with wonder, dazed. Thrills run up and down their spines, their backs straighten up, their breasts expand, their eyes shine, their fingers open and spasm and their jaw muscles tighten. The Montenegrin is weaving and decorating his song, faster and faster, ever more beautifully and daringly, and the wet and awoken workers, ecstatic and having lost all feeling for all else, follow the song as if it were their own, more beautiful and brighter fate. ${ }^{49}$

With the "close up" of the peasants in a mythical epic poetry circle, the narrator brings us to the edge of the epic, heroic set up: the building of the bridge is, like much else in Serbian history under the Ottomans, oppressing the peasants beyond their breaking point and in the mythical circle, they identify with the heroes of the past. ${ }^{50}$ The scene has been prepared for Radisavthe epic hero.

48. Andrić, The Bridge, 30.

49. Ibid., 34. Emphasis added.

50. Andrić identifies the singer merely as a Montenegrin and cites an epic poem about the gathering of Serbian nobles-two details that suggest an intertextual reference to Petar Petrović Njegoš and his epic poem The Mountain Wreath. In this most well-known instance of national mythopoesis in the epic key, Njegoš also opens his poema with a gathering of nobles. See Petar Petrović Njegoš, The Mountain Wreath, trans. Vasa D. Mihailovic (Belgrade, 1997). 
And yet, this is how our hero enters:

Among the countless peasants pressed for hard labor there was some Radisav from Unište, a small village right there above the town. A smallish man, with a gloomy face and restless eyes, bent over in the waist quite a bit, he walked briskly, spreading out his legs and waving his head and shoulders left to right, right to left, as if he were sowing wheat. ${ }^{51}$

Needless to say, these are not the looks of an epic hero. Radisav's physical description reveals his characterization not as a hero like Czar Stefan from the Montenegrin's song, not even a warrior, but a rather pathetic, small, everyday peasant. And yet, there is something deceptive about him: "He was not as poor as he appeared to be, nor as simple as he made himself out. His family were known as Heraci ... So small, bowed, and hurried, this Radisav had been scurrying about from one stable to the next these autumn nights "sowing" revolt and had insinuated himself among the peasants like an awl, whispering and counseling with only one at a time." 52

Radisav here quite literally interrupts the epic circle in Andrićs narration, the space in which the peasants are mesmerized by the Montenegrin's singing. Rather than joining the circle, he insinuates himself within it, penetrating "like an awl," a sharp, pointed spike (foreshadowing his own impalement), in order to agitate and organize the peasants.

Radisav is soon revealed to be neither a mythical force (as children's' memories would have it) nor a great martyr (as the Christians in town believe) but rather a revolutionary, and at that, not a proto-national one but a protosocialist one. Radisav tries to convince his fellow peasants to join him in secretly destroying the bridge overnight and spreading rumors that supernatural vilas are to blame: 53 "You can see for yourself that this building work will be the death of all of us. ... For us this work means extermination and nothing less. A bridge is not needed by the poor and the rayah, but only by the Turks; we neither raise armies nor carry on trade, the ferry is more than enough for us." 54

Radisav conjures up an image of a community here that is not defined by past glory, present heroes, or religious belonging-the building blocks of what would become national narratives of Serbian suffering. He draws a line between the "rayah and the poor" on the one hand and those who "raise armies" and "carry on trade" on the other. His argument to his fellow peasants here is class-based: the poor and the rayah have no use for the bridge and yet are dying on it, having abandoned their own fields. Radisav is not invoking Serbian nobles, Czar Stefan, "old patriarchs," "nine bishops," and the remaining cast of the Montenegrin's oral epic-the point of origin for Serbian national narratives in the nineteenth century. He is not even invoking the mythically evil Abidaga-who would be the corresponding villain from the oral epic form. Instead, he invokes a discourse of class opposition, structural

51. Ibid., 34. Emphasis added.

52. Ibid.

53. Vilas are the supernatural creatures from Slavic folklore, akin to fairies.

54. Ibid., 34-35. 
relations between the peasant communities on the one hand and the elite and traders on the other, even if that class opposition in Ottoman times for the most part aligned with what would become pre-national communities. ${ }^{55}$ In other words, in contrast to the Montenegrin, Radisav addresses them as peasants, not as Serbs.

Like a good Party organizer, Radisav speaks to the peasants individually, not giving a political speech, but quite clearly agitating. Finally, to ensure that we have noticed the difference between the mythical Czar Stefan from the Montenegrin's song and Radisav, and to ensure we don't forget this clear signal of Radisav's revolutionary and class-oriented nature, many chapters later the first socialist in town-the student Herak-is revealed to be from the Radisav family line, some 350 years later. ${ }^{56}$

Stripped of any heroic characteristics, painted as a peasant organizer calling for an uprising against labor exploitation by the landowners and the state, Radisav succeeds in organizing the rebellion. The peasants who are enthralled by epic poetry eventually also come to believe in Radisav's concocted story that supernatural creatures are destroying the bridge overnight, and even add and embellish it. ${ }^{57}$ Important to note is that Radisav intentionally starts the rumors that a vila is destroying the bridge, but in combination with the myths coming from epic poetry, in particular the poem The Building of Skadar, the peasants further the rumor. ${ }^{58}$ The Ottoman overseer Abidaga, like Radisav, is much too rational and calculating to believe in vilas, however, and orders an investigation that in the end captures Radisav and leads him to the executioner. ${ }^{59}$ There, in the most graphic and violent scene in all of Andrić's oeuvre, Radisav is impaled and left to die a torturous death.

It is in this scene that Radisav is transformed into a martyr and a quasiepic hero, a metamorphosis, as we will see, fundamentally based on the distance between him and the people, not his conduct or appearance. At first everyone was astonished by Radisav's poor and unseemly appearance. In

55. The ethnic identifier Turk here has also sparked controversy as the term is used in contemporary discourse as an ethnic slur for Bosniaks. However, Andrić explicitly qualifies his use of this term in an addendum to the novel entitled Dictionary of Turkisms, Provincialisms, and Some Less-known Phrases: "All Turkish words are listed in that ordinarily irregular form and in that usually modified meaning in which they are used in everyday folk speech in Bosnia and Herzegovina. The terms Turks and Turkish are used often in the storytelling to also refer to Bosnian Muslim folk, but not, naturally, in the racial or ethnic sense, but as an incorrect but at the time customary colloquialism," Ivo Andrić, Sabrana dela Ive Andrića: Knjiga prva (Belgrade, 1965), 353-58. Whether we agree with Andrić as to how that term was used in history is of lesser importance. The author explicitly denies racial and ethnic meaning to the term and to insist on such meanings of the term within the novel is to speculate on the author's intentions over and against textual evidence.

56. Heraci being the plural form of Herak.

57. Andrić, The Bridge, 36.

58. The Building of Skadar was one of the epic poems included in Vuk Karadžić's collections. For an English translation see Milne Holton and Vasa D. Mihailovich, trans. and ed., Songs of the Serbian People: From the Collections of Vuk Karadžić (Pittsburgh, 1997), 78-85.

59. Here is another challenge to the epic tales in Andrić: they are literally insufficient to protect the peasants from their overlords. They may soothe the peasants' imagination but they have no effect on Abidaga. 
all, "he seemed to all those there too wretched and too insignificant to have done the deed which now brought him to execution." Only the white stake he was carrying "gave the scene a gruesome significance and attracted all eyes to it." ${ }^{60}$ At the point of execution, the people are only a hundred feet away and can see the execution clearly, "but could not hear words or perceive details."61

The readers, however, are afforded a privileged point of view of the execution: high above and up close, one that is not available to the people who are witnessing the execution-as the narrator stresses repeatedly. The execution itself is conducted in the space of the future kapija, the central part of the bridge: "There, high above the water was a boarded space about the size of a small room. On it, as on a raised stage, they took their places, Radisav, Pljevljak and the three gypsies, with the rest of the guards posted around them on the staging." ${ }^{2}$ The theatricality of the execution also signals its social role: it is meant to instill fear in the populace but also demonstrate quite clearly the power of the state over one's very body. ${ }^{63}$

There can hardly be any mistake about the brutality of the execution-the very thing both on display and hidden from the audience. It begins, interestingly, with the executioner. The gruesomeness we are to witness is introduced as that which is gruesome for the executioner: "the most horrific part of the executioner's job," was having to use a knife to "widen the opening through which the stake would enter the body." ${ }^{4}$ This, the narrator says, was "luckily hidden from the audience." From this point on, the readers perceive everything the executioner perceives, while the "audience" sees very little. ${ }^{65}$

The brutality rivals anything we could find in descriptions of medieval torture, and yet, is quite different from those public displays. Once the stake is positioned appropriately, it enters the body with the loud sound of the mallet, audible to the spectators as well. We, on the other hand, see the executioner Merdžan doing his job conscientiously, per Abidaga's instructions to keep the peasant alive on the stake as long as possible: "At every second blow the gipsy went over to the stretched-out body and leant over it, examining whether the stake was going in the right direction and when he had satisfied himself that he did not injure any of the most important living internal organs, he returned and went on with his work." 66

The mechanics of the execution are described naturalistically, but from the perspective of the executioner and his job, not the victim. In fact, most of the time here, Radisav is no longer referred to by name, but simply as the

60. Andrić, The Bridge, 47.

61. Ibid.

62. Ibid., emphasis added.

63. In the previously cited article on Kosta Hörmann, I discuss at length the AustroHungarian empire's forms of punishment as modern rather than medieval or feudal.

64. Andrić, The Bridge, 49.

65. Slavko Leovac described this element of the scene as well, namely, that each time the executioner is observing Radisav, we are afforded the same view. Slavko Leovac, “Andrićeva na Drini ćuprija” Književnost no. 66 (1978): 1734-35.

66. Andrić, The Bridge, 49. 
body. At this point, once again, we are reminded that "All of that was scarcely heard and even less seen from the banks." 67

We see that "the body of the peasant, spread-eagled, writhed convulsively; at each blow of the mallet his spine twisted and bent." ${ }^{68}$ But, importantly, we also hear and it is the audible details, once again imperceptible to the spectators that communicate the horror of the torture:

Those nearest could hear how the man beat with his forehead against the planks, and, even more, another and unusual sound, that was neither a scream, nor a wail, nor a groan, nor anything human, but rather the body itself, stretched out and tortured was emitting a sort of creaking and cracking like a fence that is being stomped on or a piece of wood being broken." 69

The body no longer speaks, it makes noise like an object. And yet, even this is not perceptible to the audience. This focus on the brutality of the act, however, the sounds and the sights of the impaling of a human body on the one hand, and the focus on the experience of the executioner on the other, also take something away from the would-be solemn nature of martyrdom. Leovac claims that these two contrasting features of the description are Andrićs way of suggesting the extent of the suffering, "in order to further emphasize the genuine misery of the victim and his defiance." ${ }^{70}$ I suggest otherwise, that the very distance of the audience and the focus on the executioner working on the body (no longer Radisav) tend to take our attention away from the "defiance" of the peasant that would be the basis for his future martyrdom, and refocus our attention on the act itself: the methodical, scientific, almost medical description of the stake passing through the body.

Excessively brutal, obscene even, the scene is quite literally the staging of that which cannot be staged. ${ }^{71}$ The description narrows the distance necessary for symbolic meaning. Instead, one is transfixed by the frailty of the human body, contemplating internal organs and key bodily functions. In other words, it is difficult to walk away from reading these details and not feel disgust with the human body so treated, and little else. To perform the spiritual function of sacrifice, the scene would require emotions and reactions different from disgust: terror, awe, veneration, sublime wonder, solemn appreciation, and/or contemplation of the magnanimity of the sacrifice. All that is lost in the scene: we are too close to the body, its internal organs, the sounds of its destruction, and its objectification to be able to step away from the mesmerizing scene in order to consider any symbolic elevation of the torture and execution into religious or national sacrifice. Symbol, like metaphor, is premised on distance not afforded us in this passage.

Such lofty emotions and reactions, however, are perceptible in an audience that has not fully witnessed the obscene:

67. Ibid.

68. Ibid.

69. Ibid., emphasis added.

70. Leovac, “Andrićeva na Drini ćuprija,” 1735.

71. I want to thank Guadalupe González Diéguez and Margaret Graves for suggesting this aspect of the theatricality of the scene. 
A murmur and a wave of movement passed through the onlookers on both banks. Some lowered their eyes and others went quickly home without turning their heads. But the majority looked dumbly at this human likeness, up there in space, unnaturally stiff and upright. Fear chilled their entrails and their legs threatened to give way beneath them, but they were still unable to move away or take their eyes from the sight. ${ }^{72}$

It is their distance that accounts for their ability to read Radisav as a martyr. Their distance from the torturous death, not their perception of it, fuels the mythologizing of Radisav's sacrifice and its transformation into the sublime. ${ }^{73}$

There is also a strong accent on how the execution itself, the martyrdom, makes Radisav into someone he is not-his face becomes a mask, his body a statue:

The eyes were wide open and restless, but the eyelids were unmoving, the mouth was wide open but the two lips stiff and contracted and between them the clenched teeth shone white. Since the man could no longer control some of his facial muscles, the face looked like a mask.

And on that open space, raised a full eight feet upright, stiff and bare to the waist, the man on the stake remained alone. From a distance it could only be guessed that the stake to which his legs had been bound at the ankles passed right through his body. So that he seemed to the people like a statue hovering in air, on the very edge of the scaffolding, high above the river. ${ }^{74}$

Staging, masks, and statues-the stuff of tragedy. The theatricality of the execution begins, in fact, with the moment of Radisav's capture and torture:

The whole place shone, warmed and solemn. In general, that gloomy and unseemly building all at once grew, widened out, and transformed itself. In the stable and around it reigned a sort of solemn excitement and a special kind of silence that always reigns in places where justice is being sought, a living man is tortured, or where fateful things occur. Abidaga, Pljevljak, and the bound man moved and spoke like actors, while all others tiptoed with lowered eyes not speaking save when forced to and then only in whisper. ${ }^{75}$

This almost religious imagery is not perceived by the townsfolk-they only witness its final act on the "raised stage." In the end, distanced as they are from the body, it is through this staging of impalement that the audience is able to interpret Radisav as a tragic hero and a (national) martyr.

72. Andrić, The Bridge, 50.

73. Andrić similarly plays with the notion of proximity to torture and execution of innocent peasants in his other great novel, Bosnian Chronicle. There, the crowd surrounding the execution begins to jostle and fights break out between those closest to the scene (who are attempting to avert their eyes and put some distance between them and the execution) and those behind them (who, precisely beause they do not perceive the scene directly, are thus enthralled with it and want to come closer). This push and pull in the crowd can also be read as the well-known morbid fascination with violence, a stereotypical revulsion and attraction to gruesome scenes of human destruction. Ivo Andrić, Bosnian Chronicle, trans. Joseph Hitrec (New York, 1963), 269-70.

74. Andrić, The Bridge, 50, emphasis added.

75. Ibid., 45. 
Pljevljak, Abidaga's subordinate charged with the investigation and execution, on the other hand, having witnessed all the gruesome details we have, responds by going mad. The madness manifests in his desire to keep moving his limbs as a way to convince himself he is still alive, that his key internal organs are still intact, that his body is not the stiff unmovable object erected on the stage. Pljevljak's reaction confirms the execution is that which cannot be seen, cannot be staged, for it results in insanity rather than spiritual catharsis.

In a parallel to the cross that becomes the symbol of the act of crucifixion in the Bible, the impalement (stake) becomes the symbol of Ottoman oppression in the Serbian epic mode. Parallels with Christ in the scene are obvious in other ways, but especially in the myth of Radisav's resurrection. ${ }^{76} \mathrm{His}$ name, in fact, is also significant, whether the root comes from the verb to work (raditi) or to rejoice (radovati se) and either glory (slava) or all (sav). All work or rejoice in the glory (of Christ, presumably). This duality (proto-socialist or Christ) is key for what I argue here, as it is precisely because his death is set up to be read as solemn religious sacrifice that the quoted narrative shifts and details can present an argument against such elevation of Radisav's death. The ironic ambiguity inherent in this duality as well as the polyvalent nature of the scene of Radisav's impalement interrupts the oral epic form and content, rather than affirming it.

Even more importantly, Radisav is also not fulfilling the role epos dictates: a human sacrifice that the bridge, like all great human endeavors "requires," as in The Building of Skadar. It is precisely at the moment of his impalement when the crowd silently, dumbly stares at the figure of Radisav that the story of immurement is brought up again, separate from Radisav: the crazy young woman Ilinka (who imagined her stillborn children were the rumored immured victims) wanders through the silent crowd, peering into people's eyes, oblivious to Radisav but attempting to "read and discover where her sacrificed and buried children might be." 77 The mythical immurement role in the novel, however, is reserved for a young African, a "distant echo" of empire and imperial expansion embodied in a typical medieval Mediterranean hybrid character.

The mythically evil Abidaga is relieved of his duties shortly after the execution. He is reported by Tosun Efendi for embezzlement of funds and replaced by Arifbeg, the "calm, normal and honest man" who completed the construction without further delays. Arifbeg and Tosun Efendi bring with them an international cast of characters, technological specialists from beyond the Ottoman Empire, namely, Master Antonio and with him skilled workers from Dalmatia, Greece and elsewhere. One such worker was a young black man from Ulcinj on the Montenegrin coast, "where a few black families still lived," and whom Master Antonio befriended as a child. This motley crew of Mediterranean characters speaks a "strange composite language which had been evolved in the course of years between these men from all parts of the

76. On Radisav's martyrdom and parallels with Christ, see also Longinović, "East within the West,"133-34.

77. Andrić, The Bridge, 50. 
world," and in many ways they symbolize the medieval, cosmopolitan, hybrid culture of the Mediterranean, which Andrić assigns a special role in his other famous novel, Bosnian Chronicle. ${ }^{78}$

This young man, descendent of the pirates, exotic and perceptibly different, is accidentally immured into the bridge at the same symbolically-important kapija, as the final stone for the central pier of the bridge is lowered. When the ropes gave way, "the block fell, first by one corner and then with its full weight on to the excited Arab who had not even troubled to look above his head but only down at the water. By a strange chance the block fell exactly into position, but in its fall caught the Arab and crushed the whole lower part of his body."79

His death, unlike Radisav's, is clean, barely perceptible. We learn only that the "flow of blood poured out, the young man's breath came short and his eyes glazed over." The young man died "clutching Mastro Antonio's hands in his" and was given a solemn funeral long remembered. ${ }^{80}$

He, not Radisav (who intentionally starts the mythical immurement story as part of his rebellion), becomes that symbolic sacrifice. It is only after his death that the bridge becomes finally recognizable as a bridge: "At the same time, that formless mass of crisscrossed beams and pieces over the river started to deflate and thin, so that through it, now, the true bridge made of beautiful white stone, was becoming more clearly visible." ${ }^{11}$ The mythical immurement stresses here the victims of empires, those left behind by various waves of imperial occupations, in other words, not the Serbian national hero but the young African, from a family "lost" in Ulcinj.

We thus come to the final undoing of the Radisav/national myth: the human sacrifice, the real tragedy that makes the bridge possible is drawn from the interplay of empires in the Balkans-the very theme that defines Višegrad's history covered in the novel: empires and the fates of people caught in their comings and goings through the Balkans. In other words, empire rather than nation, class, rather than ethnos.

While I can only point to this broader interpretation of the novel captured in the above binaries, it is clear that the Radisav myth, for so long the lightening rod in nationalist interpretations of Andrić, in fact operates as the site of Andrić's most in-depth undermining of national narratives. From Radisav's class concerns to his less-than-heroic presentation, his contrast to the heroes of the Montenegrin's song to his mediated execution, and finally, the complete reversal in the role of mythical human sacrifice where the young Arab takes Radisav's place, it is clear that Andric is attempting to shift the focus of his tale away from national epos and towards a critical assessment of the role and effects of empires and their rivalries played out in the Balkans and the world

78. The reference in the "still lived" is to the role of the so-called "Barbary pirates" who helped Ottomans capture the town from the Venetians. For more on the typically Mediterranean characters in Andrić see Milutinović, Getting over Europe, 225-60.

79. Andrić, The Bridge, 63.

80. Ibid.

81. Ibid., 64. 
at large. This should not be surprising considering the particular nature of the Young Bosnian anti-colonial nationalisms with which Andrić sympathized.

As we have also seen, however, the formal features of Andrićs text also hint at a general undoing of the epic mode formally. The novel repeatedly sets up seemingly epic features: narrative distance, digressions, and the interplay of myth and reality. But as Zdenko Lešić notes, "this is only seemingly an approach of a traditional epic narrator, one who sees all and knows all, one who from 'high on up,' as if from some 'narrative Olympus,' passes judgement on and about people." In reality, Andrić's narration is "by no means epically distant, 'objective,' 'all-knowing,' and 'god-like' (in a Homeric sense), even if it may appear so at times." 82 Andrić indeed sets up this Olympus from which the narrator speaks; he deploys numerous digressions and banks on the interplay of myth and reality, but only so as to disrupt them with ironic reversals, cinematic close ups, and situational rhymes that establish the text as a polyphonic, modernist novel. This is a dichotomy Andrić sets up early on and in direct reference to the young Arab (rather than Radisav):

The children gaze into that dark opening from the bank as into the abyss which both terrifies and fascinates. They agree to look at it without blinking, but whoever first sees anything is to cry out. Open-mouthed they peer into that deep dark rupture, quivering with curiosity and fear, until it seems to some anemic child that the opening begins to sway and move like a black curtain, or until one of them, sneering and cynical friends (there is always at least one such) shouts 'Arab' and pretends to run away. That spoils the game and arouses disillusion and indignation among those who love the play of imagination, hate irony and believe that by looking intently they could actually see and experience something. ${ }^{83}$

To place Andrić among the one or the other camp here identified with children is difficult, even though it might seem he belongs with those sneering and cynical friends, as irony defines so much of Andrić's narrative presence. And yet, I want to propose that it is precisely this curious combination of the epic and the modern, the earnest and the ironic that is key to understanding Andrić's place in modern literature.

In short, this particularly-odd narrative form that combines epic digressions with the modern structure of the novel premised on irony and situational parallels has been described by Franco Moretti as a world-text form-a modern epic. ${ }^{84}$ Like Moretti's modern epic, The Bridge on the Drina is an "encyclopedic gesture," a "super-canonical" text, yet "virtually unread" (at least in proportion to how often it is referenced). At its heart, it is "flawed" in that it reveals an antagonism or "discrepancy between the totalizing will of the epic and the subdivided reality of the modern world," embodied in our case in the earnestness and irony in the children's game above. ${ }^{85}$ Out of this double

82. Lešić, Pripovjedači, 139-41.

83. Andrić, The Bridge, 16.

84. Moretti, Modern Epic. World-text is a signal to Immanuel Wallerstein's theory of world-system as Moretti will link the modern epic particularly to Wallersteinian concepts of center and peripheries in the modern world.

85. Ibid., 5. 
bind of wanting to challenge the legitimacy of (oral epic) tradition, while also wishing to establish its own greatness, the modern epic-as an inherited form that desires the epic encyclopedic vision but also recognizes it cannot believe in it (as the children do)-turns to irony as a "splendid defense mechanism" that "allows the epic to survive in the new world." ${ }^{86}$ Hence, the prevalence of irony, however gentle it may at times be, in Andrićs novel.

The modern epic as a world-text registers the social reality or, rather, attempts to symbolically resolve real social contradictions, of peripheral or semi-peripheral spaces. ${ }^{87}$ In Andrićs's case, this is modernization, or the arrival of capitalism in Bosnia, in that particularly odd form of an already failing, peripheral Austro-Hungarian Empire's final grasp on power. This is that tension between the bridge and the train Milutinović identified, the premodern space-time and modern order, or rather between feudalism and capitalism, which signals this peripheral position and its combined and uneven development. Importantly, however, it is the narrative form itself in Andrićs modern epic, that I claim also captures and mediates these social conditions, attempting to resolve them in the polyphony of ironic reversals and thwarted desires for an encyclopedic totality. In this combined mode, Andrić speaks not (just) as the chronicler of olden Bosnia but a poet of its modernity.

86. Ibid., 38-39.

87. The latest intervention in debates on world literature revives Moretti's reference to Wallerstein's world-systems theory in proposing world-literature as the literature of the modern, capitalist world-system. Warwick Research Collective, Combined and Uneven Development: Towards a New Theory of World Literature (Liverpool, 2015). See also Fredric Jameson, The Political Unconscious: Narrative as a Socially Symbolic Act (Ithaca, 1981). 